\title{
Linking global economic dynamics to a South African-specific credit risk correlation model ${ }^{\text {th }}$
}

\author{
Albertus H. de Wet ${ }^{a}$, Reneé van Eyden ${ }^{\text {b,* }}$, Rangan Gupta ${ }^{\text {b }}$ \\ a Balance Sheet Management, FirstRand Bank, South Africa \\ ${ }^{\mathrm{b}}$ Department of Economics, University of Pretoria, South Africa
}

\section{A R T I C L E I N F O}

Article history:

Accepted 24 February 2009

Available online $\mathrm{xxxx}$

\section{JEL classification:}

C32

C51

E44

\section{Keywords:}

Credit portfolio management

Multifactor model

Vector error-correcting model (VECM)

Credit correlations

\begin{abstract}
A B S T R A C T
In order to address practical questions in credit portfolio management it is necessary to link the cyclical or systematic components of firm credit risk with the firm's own idiosyncratic credit risk as well as the systematic credit risk component of every other exposure in the portfolio. This paper builds on the methodology proposed by Pesaran, Schuermann, and Weiner [Pesaran, M.H., Schuermann, T., and Weiner, S.M., (2004), Modeling regional interdependencies using a global error correcting macroeconometric model, Journal of Business and Economic Statistics, 22, 2, 129-169.] and supplemented by Pesaran, Schuermann, Treutler and Weiner [Pesaran, M.H., Schuermann, T., Treutler, B., and Weiner, S.M., (2006), Macroeconomic dynamics and credit risk: a global perspective, Journal of Money, Credit, and Banking, Volume 38, Number 5, August 2006, 1211-1261.] which has made a significant advance in credit risk modelling in that it avoids the use of proprietary balance sheet and distance-to-default data, focusing on credit ratings which are more freely available.

In this paper a country-specific macroeconometric risk-driver engine which is compatible with and could feed into the GVAR model and framework of PSW (2004) is constructed, using vector error-correcting (VECM) techniques. This allows conditional loss estimation of a South African-specific credit portfolio but also opens the door for credit portfolio modelling on a global scale, as such a model can easily be linked to the GVAR model. The set of domestic factors is extended beyond those used in PSW (2004) in such a way that the risk-driver model is applicable for both retail and corporate credit risk. As such, the model can be applied to a total bank balance sheet, incorporating the correlation and diversification between both retail and corporate credit exposures

Assuming statistical over-identification restrictions, the results indicate that it is possible to construct a South African component for the GVAR model that can easily be integrated into the global component. From a practical application perspective the framework and model is particularly appealing since it can be used as a theoretically consistent correlation model within a South African-specific credit portfolio management tool.
\end{abstract}

(c) 2009 Elsevier B.V. All rights reserved.

\section{Introduction}

Since the early 1990s intense competition for market share has motivated banks across the globe to allow credit portfolios to become less diversified (across all dimensions - country, industry, sector and size) and accept lesser quality assets on their books without being adequately compensated for the higher risk. As a result, even wellcapitalised banks could come under severe solvency pressure when global economic conditions turn. The banking industry have realised the need for more sophisticated loan origination and credit and capital management practices.

Any views expressed represent those of the authors only and not necessarily those of FirstRand Bank.

* Corresponding author. Department of Economics, University of Pretoria, Pretoria, 0002, South Africa. Tel.: +27 12420 3456; fax: +2712 3625207

E-mail address: renee.vaneyden@up.ac.za (R. van Eyden).
From a credit portfolio perspective it is essential that portfolio managers understand the dynamics and interaction of two key elements of their exposures, namely, systematic and idiosyncratic risk. Systematic risk refers to the co-movement and risk associated with the relationship between exposures and the general economic environment while idiosyncratic risk refers to exposure-specific risk factors such as leverage or cash flow ratios. In order to perform meaningful credit portfolio management it is necessary to be able the to link cyclical or systematic components of firm credit risk with the firm's own idiosyncratic credit risk, as well as the systematic credit risk component of every other exposure in the portfolio. In general, this relationship is referred to as credit correlation. Conceptually one would expect that the correlation of individual exposures with the business cycle would imply that in an economic downturn portfolio credit risk is increased by the simultaneous increase in risk of exposures which are sensitive to the same macroeconomic variables. A better understanding of these correlations would not only allow better 
capital budgeting over the business cycle but would also allow portfolio managers to execute and more effectively exploit market opportunities.

The methodology proposed by Pesaran, Schuermann and Weiner (2004) (PSW) and Pesaran, Schuermann, Treutler and Weiner (2006) (PSTW) has made a significant advance in credit risk modelling by linking an adjusted structural default model to a structural global econometric model (their global vector autoregressive (GVAR) model), from which conditional credit risk analysis and portfolio management can be done. In general the methodology can be described as comprising two parts: the first is a macroeconomic simulation engine (normally refer to as the "correlation model" in the credit portfolio literature) while the second part is a set of firm-specific default models which translates the macroeconomic conditions into credit risk outcomes. This paper investigates the possibility of constructing a country-specific macroeconometric risk-driver engine which is compatible with the GVAR model and framework. This will allow conditional loss estimation of a South African-specific credit portfolio but also opens the door for credit portfolio modelling on a global scale, because such a model can easily be linked to the GVAR model.

The paper is structured as follows. The first and second sections discuss the basic problems faced by bank credit portfolio managers across the globe, then highlight the methodology and framework proposed by PSW (2004) and PSTW (2006) to develop a consistent econometric framework and model to estimate the dynamics of global credit markets, which is shown in Section 3. Section 4 provides an indepth discussion on the data construction process, estimation results, dynamic properties and forecasting ability of the proposed South African-specific vector error-correcting model (VECM). The paper concludes in Section 5 by arguing that the proposed model could be used as a stand-alone correlation model in a South African-specific credit portfolio model or could be linked to the GVAR model as part of a global credit portfolio management tool.

\section{Credit risk and the macroeconomy}

Much of the discussion taking place since the introduction of the New Capital Accord under Basel II (BIS, 2006) has centred on the effects of business cycles on portfolio credit risk and economic capital (see, for example, Carpenter et al., 2001; Carey, 2002; Allen and Saunders, 2004; Jarrow and van Deventer, 2005; Elizalde, 2005). However, most approaches have opted to represent the general economy or systematic risk by a single risk factor. The systematic component of all exposures, the process generating asset values, and therefore the default thresholds, are assumed to be homogeneous across all firms. Indeed this asymptotic single risk factor (ASRF) model (Gordy, 2003) has been the foundation for Basel II. While the ASRF framework is appealing due to its analytical closed-form properties for regulatory and generally universal application in large portfolios, the single risk factor characteristic is also its major drawback. Essentially it does not allow for enough flexibility in answering real life questions. Commercially-available credit portfolio models made an effort to address this by introducing more systematic factors in the asset value generating process but have failed to provide any tractable economic meaning to their risk factors.

The methodology proposed by PSW (2004) and PSTW (2006) provides an applicable model for conditional credit loss modelling which combines the systematic risk with the idiosyncratic component of each exposure and also includes an explicit channel for default correlation. The methodology is particularly appealing in that it is not only flexible in answering practical portfolio questions (through scenario analysis) but also steers away from the data confidentiality problem that most practitioners face with commercially available credit portfolio models. In simple terms the methodology can be summarised as follows. The macroeconometric risk-driver model will specify and represent the macroeconomic environment in which the credit portfolio operates. Using Monte Carlo simulations, various possible simulation paths of the economy are forecasted over a specific period. These macro factors feed into the firm-specific return models in order to produce the asset value generating process of each firm. Using the return dynamics and the estimated equity default thresholds from PSTW (2006), the probability of default can be obtained through a structural-based credit default model. Finally, a conditional loss distribution for the credit portfolio is obtained and used to estimate various credit-related parameters such as economic capital and allow for various scenario analyses to be performed.

Although the earlier versions of the GVAR model as constructed by Pesaran et al. (PSW) (2004) and Pesaran et al. (2006) did not include a South African component, a later version by Dees et al. (2007), expanded their coverage to include South Africa under the "Rest of World" group of countries. However, their specification and estimation for the South African economy is based on the general specification used while the cointegration identification is based on exact-identified restrictions, identifying one cointegrating vector for South Africa.

In this model the aim is not only to incorporate South Africa into the current GVAR model, but to provide theoretical consistent identification restrictions, and also, to include variables which are appropriate for bank retail and corporate credit portfolios. Given the fact that most of the existing simulation models that underpin credit portfolio models are not, to a significant extent, based on economic theory (relying on Gaussian simulation based methodology), this model could provide significant insight into the macroeconomic and credit portfolio exposure linkages.

Our aim in this paper, is therefore to construct a South Africanspecific macroeconometric risk-driver engine which is compatible with the global vector autoregression (GVAR) model and framework proposed by PSW (2004). This will allow conditional loss estimation of a South African-specific credit portfolio, but also opens the door for credit portfolio modelling on a global scale, as such a model can easily be linked into the already established GVAR model. A significant enhancement to the set of domestic factors included in the VECM model is made to allow the incorporation of both corporate and retail credit risk elements to be modelled from the same system. This would allow simultaneous estimation of total bank portfolio credit risk, which accounts for correlation and diversification between corporate and retail credit exposures. In order to estimate and provide such a South African-specific model it is therefore necessary to analyse the construction of the GVAR model proposed by PSW (2004).

\section{The PSW GVAR model}

The macroeconometric risk-driver model (GVAR) used in PSW (2004) comprises a total of 25 countries which are grouped into 8 regions and account for $82 \%$ of world production. However, as stated by PSW (2004), a cointegration framework can become computationally very demanding and, for this reason, seven key economies are modelled alone, including the U.S., U.K., Japan, China, Germany, France and Italy while all other countries are modelled as part of the regional groups, i.e. Western Europe, South East Asia, Latin America and the Middle East. In the case of South Africa, the GVAR model lacks applicability since it does not include an African region. However, the approach is general enough so that country-specific cointegration models can be linked into the global and already established GVAR model. Therefore, the use of cointegration is applied in such a fashion that heterogeneity that exists across regions and countries is acknowledged. This section draws on the core elements of the GVAR model as presented in PSW (2004) to illustrate the framework and put the methodology in context. ${ }^{1}$

\footnotetext{
Refer to PSW (2004) for a full presentation of the methodology.
} 
In general, the GVAR model proposed by PSW (2004) allows for interaction amongst countries and economies through three channels:

- Contemporaneous dependence between the endogenous variables (domestic $\left(\mathbf{x}_{i t}\right)$ and global $\left(\mathbf{x}_{i t}^{*}\right)$ ) and their own lagged values;

- Dependence of country-specific variables on common global effects such as oil prices; and

- Weak cross-section dependence of the idiosyncratic shocks between countries.

This specification by PSW (2004) provides a complete system of $(N+1)$ country-specific variables which can be estimated simultaneously if data permits. Moreover, the dynamic, stability and forecast ability of the GVAR model is proven, which makes it a suitable framework for credit portfolio model scenario and impulse response analysis (e.g. general impulse response analysis as argued in Koop et al., 1996; Pesaran and Shin, 1998; Pesaran and Smith, 1998). However, the number of parameters that needs to be estimated in such a global model is often more than the number of data observations available.

\subsection{Using individual country models to estimate the GVAR model}

The GVAR model is theoretically very appealing but estimation of the model as a single system would not be feasible for moderately high values of $N$. In fact, PSW (2004) argues that the number of parameters that need to be estimated is often more than the number of data observations available. As such, it would seem as if the model is practically unusable.

However, PSW (2004) makes a significant enhancement to the framework by proving that the model can indeed be estimated through individual country models on a name-by-name basis rather than simultaneously and therefore is feasible for large values of $N$. Essentially the conditions under which the individual country VECM models would lead to similar results as modelling the full model simultaneously, provide a formal definition of a small open economy. In the context of this study this condition will suffice since South Africa can certainly be regarded as a small open economy in the global context.

Under weak exogeneity conditions, the parameters of the countryspecific models can be estimated using the reduced-rank approach pioneered and developed by Johansen $(1989,1992,1995)$. As such, one allows for the possibility that the levels of the macroeconomic variables might be cointegrated in the long run. Although the method developed by Johansen assumes that all variables are endogenously determined and of order I(1), Pesaran, Shin and Smith (2000) have modified the methodology to allow for weakly exogenous variables to be included in a reduced-rank estimation procedure.

Therefore to estimate the country-specific models subject to reduced-rank restrictions and including a vector of common exogenous variables in the system (e.g. oil prices) $\boldsymbol{d}_{t}$ where $\boldsymbol{d}_{t}$ is a $s \times 1$ vector, the country-specific model which governs the long-run relationships between the $k_{i} \times 1$ vector of domestic $\left(\boldsymbol{x}_{i t}\right)$ and $k_{i}^{*} \times 1$ vector of global $\left(\boldsymbol{x}_{i t}^{*}\right)$ variables is:

$$
\begin{gathered}
\boldsymbol{x}_{i t}=\mathbf{a}_{i 0}+\mathbf{a}_{i 1} t+\Phi_{i} \mathbf{x}_{i, t-1}+\Lambda_{i 0} \mathbf{x}_{i t}^{*}+\Lambda_{i 1} \mathbf{x}_{i, t-1}^{*}+\boldsymbol{\psi}_{i 0} \mathbf{d}_{t}+\boldsymbol{\psi}_{i 1} \mathbf{d}_{t-1}+\boldsymbol{\varepsilon}_{i t}, \\
t=1,2, \ldots, T, \quad i=1,2, \ldots, N,
\end{gathered}
$$

while the error correction model is represented by:

$\Delta \mathbf{x}_{i t}=\mathbf{a}_{i 0}+\mathbf{a}_{i 1} t+\Pi_{i} \mathbf{v}_{i, t-1}+\Lambda_{i 0} \Delta x_{i t}^{*}+\boldsymbol{\psi}_{i 0} \Delta \mathbf{d}_{t}+\boldsymbol{\varepsilon}_{i t}$,

where

$\Pi_{i}=\left(\mathbf{A}_{i}-\mathbf{B}_{i}, \boldsymbol{\psi}_{i 0}-\boldsymbol{\psi}_{i 1}\right)$, and

$\mathbf{v}_{i, t-1}=\left(\begin{array}{c}\mathbf{z}_{i, t-1} \\ \mathbf{d}_{t-1}\end{array}\right)$.

with

$\mathbf{z}_{i t}=\left(\mathbf{W}_{i} \mathbf{x}_{t}\right), \quad i=0,1,2, \ldots . N$,

where $\mathbf{W}_{i}$ is a $\left(k_{i} \times k_{i}^{*}\right) \times k$ matrix of fixed constants defined in terms of the country-specific weights. PSW (2004) define $\mathbf{W}_{i}$ as the "link" matrix which allows the individual country models to be written in terms of the global variable vector, $\boldsymbol{x}_{i t}^{*}$.

Furthermore

$A_{i}=\left(I_{k i},-\Lambda_{i 0}\right)$ and $B_{i}=\left(\Phi_{i}, \Lambda_{i 1}\right)$ are $k_{i} \times\left(k_{i} \times k_{i}^{*}\right)$ and $A_{i}$ has full row rank, i.e. $\operatorname{rank}\left(A_{i}\right)=k_{i}$,

where $\Phi_{i}$ is a $k_{i} \times k_{i}$ matrix of lagged coefficients, $\Lambda_{i 0}$ and $\Lambda_{i 1}$ are $k_{i} \times k_{i}^{*}$ matrices of coefficients associated with the foreign-specific variables, and $\varepsilon_{i t}$ is a $k_{i} \times 1$ vector of idiosyncratic country-specific shocks which are serially uncorrelated with mean 0 and a non-singular covariance matrix, $\boldsymbol{\Sigma}_{i i}=\left(\boldsymbol{\sigma}_{i i, l s}\right)$.

The information regarding the long-run cointegration relationships between the levels of the variables is contained in the $\left(k_{i}+k_{i}+s\right) \times 1$ matrix, $\Pi_{i}$. If there is no cointegration amongst the variables $\Pi_{i}=0$ and Eq. (2) reduces to the normal first difference model:

$\Delta \mathbf{x}_{i t}=\mathbf{a}_{i 0}+\Lambda_{i 0} \Delta \mathbf{x}_{i t}^{*}+\boldsymbol{\psi}_{i 0} \Delta \mathbf{d}_{t}+\boldsymbol{\varepsilon}_{i t}$.

In general, one would expect $\Pi_{i} \neq 0$, since there should be important interlinkages between the economic variables (between both domestic variables themselves and with foreign variables). However $\Pi_{i}$ would probably be rank deficient so that $\operatorname{rank}\left(\Pi_{i}\right)=r_{i}<k_{i}$ and therefore the error-correcting model in Eq. (2) needs to be estimated using reduced-rank restrictions as proposed by Johansen (1989; 1992; 1995).

\section{Estimating a South African component for the GVAR model}

Using the methodology outlined above, the construction of seven country-specific and four region-specific models culminates in the GVAR model which captures the dynamics of 25 countries' macroeconomic developments. However, since the GVAR model lacks an African element, in this section the PSW (2004) methodology is applied to South Africa and provides an individual country model which is believed to be compatible with the GVAR model. This step adds an African component which is currently excluded from the GVAR model.

\subsection{Foreign trade weights}

The impact that the global economy has on domestic macroeconomic dynamics is captured by constructing a country-specific global time series of economic variables. These time series is constructed through weighting South Africa's major foreign role players' individual economic time series by utilising foreign trade weightings. While PSW (2004) uses United Nations net trade flow data to determine weighting estimates, the weights used in our model are determined as set out below.

With global integration and an ever-increasing free trading environment, South Africa has seen an increase in the number of its major trading partners over the last decade. To this effect, the South African Reserve Bank has increased the number of trading partners considered in constructing the real effective exchange rate from four to fourteen to more accurately reflect current foreign trade relations. 
Table 1

South African trade weights.

\begin{tabular}{|c|c|c|}
\hline Country & Weights before Jan 1999 & Weights after Jan 1999 \\
\hline \multicolumn{3}{|l|}{ Euro area: } \\
\hline Germany & $16.91 \%$ & \\
\hline Italy & $5.07 \%$ & \\
\hline France & $4.98 \%$ & \\
\hline Netherlands & $3.90 \%$ & \\
\hline Belgium-Luxembourg & $3.54 \%$ & \\
\hline Spain & $1.34 \%$ & \\
\hline Ireland & $0.86 \%$ & \\
\hline Austria & $0.83 \%$ & \\
\hline Finland & $0.81 \%$ & \\
\hline Portugal & $0.34 \%$ & \\
\hline Euro area & $38.58 \%$ & $35.70 \%$ \\
\hline USA & $14.44 \%$ & $15.15 \%$ \\
\hline UK & $14.09 \%$ & $14.91 \%$ \\
\hline Japan & $9.90 \%$ & $10.26 \%$ \\
\hline Switzerland & $4.99 \%$ & $5.28 \%$ \\
\hline China: Mainland & $2.91 \%$ & $3.11 \%$ \\
\hline China: Hong Kong & $2.59 \%$ & $2.62 \%$ \\
\hline Korea & $2.50 \%$ & $2.57 \%$ \\
\hline Zimbabwe & $2.27 \%$ & $2.27 \%$ \\
\hline Canada & $1.87 \%$ & $1.93 \%$ \\
\hline Australia & $1.59 \%$ & $1.62 \%$ \\
\hline Sweden & $1.58 \%$ & $1.79 \%$ \\
\hline Singapore & $1.55 \%$ & $1.62 \%$ \\
\hline Israel & $1.14 \%$ & $1.17 \%$ \\
\hline
\end{tabular}

Source: Walters and De Beer (1999).

According to Walters and De Beer (1999) South Africa's major trading partners are comprised of 14 countries which account for over $85 \%$ of South Africa's trade in manufacturing goods. The 14 major trade partners include the Euro area, the United States of America, the United Kingdom, Japan, Switzerland, People's Republic of China: Mainland, People's Republic of China: Hong Kong, Korea, Zimbabwe, Canada, Australia, Sweden, Singapore and Israel. Walters and De Beer (1999) present a full discussion on the Information Notice System (INS) of the International Monetary Fund's methodology used to calculate the new trade weights of South Africa and also applies the methodology retrospectively in order to provide information on the trade weights historically. The second column of Table 1 shows the final weights used to construct the global (or "starred") macroeconomic variables.

Due to the implosion of its economy over the last couple of years the inclusion of Zimbabwe skews the global variables over the near term. Zimbabwe is therefore excluded from the sample and its trade share apportioned pro-rata to the remaining foreign trading partners in the estimation process.

\subsection{Global macroeconomic variables}

Since this study is positioned to add an African component to the PSW (2004) GVAR model, it is necessary to use the same underlying data as far as possible during construction so that it is possible to link this model to the outcomes generated by the PSW (2004) model in a dynamic global simulation and forecasting framework. Therefore, in order to construct the global macroeconomic data, the same series specifications are used and the same data sources referenced as in PSW (2004) and PSTW (2006). The global variables used can be summarised as follows:

$$
\begin{array}{rlrl}
y_{i t} & =\ln \left(\frac{G D P_{i t}}{C P I_{i t}}\right), & p_{i t} & =\ln \left(C P I_{i t}\right), \\
q_{i t} & =\ln \left(\frac{E Q_{i t}}{C P I_{i t}}\right), & m_{i t} & =\ln \left(\frac{M_{i t}}{C P I_{i t}}\right), \\
\rho_{i t} & =0.25 \ln \left(1+\frac{R_{i t}}{100}\right), &
\end{array}
$$

where $i$ is an index representing the set of trading partners of South Africa as outlined above, $G D P_{i t}=$ nominal gross domestic product, $C P I_{i t}=$ consumer price index, $M_{i t}=$ nominal money supply in domestic currency, $E Q_{i t}=$ nominal equity price index, and $R_{i t}=$ nominal rate of interest per annum in \%.

The primary variables considered and data sources used in this study are therefore similar to those used and explained in PSW (2004) and are summarised in Table 2.

The construction of time-series data for the Euro area for the time period before unification in 1998 was done based on the trade weights as provided by Walters and De Beer (1998). This might have led to some significant data gaps as well as unavailable time series for some countries particularly for earlier time periods. Additionally, data series for the Euro area after 1998 may not always add up or link perfectly with the weighting system applied before 1998. We propose to deal with these issues as follows; missing data were created by first interpolating the quarterly data from the annual data where available. If annual data were not available, the quarterly data were generated by backcasting using the average of the earliest available quarterly growth rates for that series. Thereafter, the time series for the Euro area before 1998 was adjusted by scaling the data to match the data obtained from the IFS data base for the time period after 1998 . Similarly, in other data series such as for example China: Mainland and China: Hong Kong, missing data and time series were constructed first by interpolation of the annual time series or through approximation of the series by using growth rates.

In summary, the ten-country individual time series for the Euro zone before 1998 was combined into a single Euro area series for each variable by applying the country weights in Table 1, these series were augmented by the Euro time series for the time period after 1998.

In a similar fashion the foreign variables were constructed from the 14 individual economic time series by weighting them with their individual weights as obtained from Table 1 . As such, five time series from the 14 individual regional and country series will represent the dynamics of the global economic variables which are assumed to impact and shape the South African domestic economy's macroeconomic landscape. Formally the construction of the set of global variables $\mathrm{x}_{i t}^{*}$ can be described by:

$$
\begin{array}{ll}
y_{i t}^{*}=\sum_{j=0}^{N} w_{i j}^{y} y_{i t}, & p_{i t}^{*}=\sum_{j=0}^{N} w_{i j}^{p} p_{i t}, \\
q_{i t}^{*}=\sum_{j=0}^{N} w_{i j}^{q} q_{i t}, & \rho_{i t}^{*}=\sum_{j=0}^{N} w_{i j}^{\rho} \rho_{i t}, \\
m_{i t}^{*}=\sum_{j=0}^{N} w_{i j}^{m} m_{i t}, &
\end{array}
$$

\begin{tabular}{|c|c|c|}
\hline Variables & Data source & $\overline{\text { Short name }}$ \\
\hline Output (GDP) & $\begin{array}{l}\text { IMF's International Financial Statistics } \\
\text { (IFS) GDP (2000) series }\end{array}$ & $Y^{*}$ \\
\hline General price indices & $\begin{array}{l}\text { IMF's International Financial Statistics } \\
\text { (IFS) Consumer Price Index (2000) series }\end{array}$ & $p^{*}$ \\
\hline Equity price indices & Bloomberg's & $q^{*}$ \\
\hline Exchange rates & $\begin{array}{l}\text { IMF's International Financial Statistics } \\
\text { (IFS) rf. series }\end{array}$ & $e^{*}$ \\
\hline Interest rates & $\begin{array}{l}\text { IMF's International Financial Statistics } \\
\text { (IFS) series 60B (the money rate) }\end{array}$ & $\rho^{*}$ \\
\hline Money supply & $\begin{array}{l}\text { The sum of the IMF's International } \\
\text { Financial Statistics (IFS) series } 34 \text { (money) } \\
\text { and series } 35 \text { (quasi-money) }\end{array}$ & $m^{*}$ \\
\hline
\end{tabular}

where $y_{i t}, p_{i t}, q_{i t}, \rho_{i t}, m_{i t}, w_{i j}^{y}, w_{i j}^{p}, w_{i j}^{q}, w_{i j}^{\rho}$, and $w_{i j}^{m}$ are as defined above.

Table 2

Global data series and data sources. 


\subsection{Domestic and exogenous macroeconomic variables}

In the domestic economy-specific variable selection there was slight deviation from the variable selection as applied in PSW (2004). Due to the fact that this study does not aim to provide region and country-specific models for all trading partners but only to supply a South African-specific element to the GVAR model, the possibility of constructing a domestic VECM model which includes more creditmarket related variables is investigated. The number of data series is extended beyond the series used to capture the global macroeconomic environment and includes additional variables which are deemed to be important to credit markets in South Africa. Other than the output, general price levels, interest rates and money supply used for the global macroeconomic environment, the possible inclusion of two additional variables for the South African domestic economy is considered, namely household debt to income ratios and house price data.

As before, for the overlapping variables, the same data series specifications as in PSW (2004) and PSTW (2006) are used, e.g. the nominal $G D P$ is deflated by the CPI, CPI as representative of the general price level is included, rather than the inflation rate, and $E$ represents the real effective exchange rate.

Household debt to income ratios have increased significantly over the last two years of the sample period due to the structurally lower interest rate environment. Although debt repayments have been fairly stable, the absolute volume underlying credit extension can have a significantly adverse effect on the economy if interest rates were to increase to historically observed levels. As such, the household debt to income ratio is included in the set of domestic variables as it provides significant information with respect to the risk drivers of the domestic credit market.

A second significant development in the domestic market in recent times has been the increase in property values. Similar to the global trend, property prices have displayed phenomenal growth over the last three years of the sample which has led to significant wealth creation. Therefore, although the South African economy's balance sheet has seen an increase in liabilities due to higher debt, on a net wealth basis balance sheet quality has improved due to the increase in property values. For the latter reason a house price index variable has been included in the set of domestic variables in order to capture the impact and solvency risk posed to the macroeconomy by developments in the property market. Furthermore, the real house price index is generally regarded as a leading indicator of general levels of economic activity (Stock and Watson, 2003), and therefore a useful tool in uncovering potential future risk.

The set of domestic and exogenous variables and their transformations (in order to express them in real terms) are:

$$
\begin{array}{lrlrl}
y_{t}=\ln \left(\frac{G D P_{t}}{C P I_{t}}\right), & p_{t}=\ln \left(C P I_{t}\right), & d_{t}=\ln \left(\text { Household debt }_{t} / \text { Income }_{t}\right)(9) \\
q_{t}=\ln \left(\frac{E Q_{t}}{C P I_{t}}\right), & m_{t}=\ln \left(\frac{M_{t}}{C P I_{t}}\right), & h_{t}=\ln \left(\frac{H P I_{t}}{C P I_{t}}\right) \\
e_{t}=\ln \left(E_{t}\right), & \rho_{t}=0.25 \ln \left(1+\frac{R_{t}}{100}\right) & o_{t}=\ln \left(\text { Oilp }_{t}\right) .
\end{array}
$$

where $G D P_{t}=$ nominal gross domestic product, $C P I_{t}=$ consumer price index, $M_{t}=$ nominal money supply in domestic currency, $E Q_{t}=$ nominal equity price index, $E_{t}=$ real effective exchange rate and $R_{t}=$ nominal rate of interest per annum in \%. Household debt $_{t} /$ Income $_{t}=$ debt to income ratio of households, $H_{P}=$ house price index depicting the general increase in property values, and Oilp $\$ \$_{t}=$ Brent crude oil price in U.S. dollar terms.

\begin{tabular}{|c|c|c|}
\hline Variables & Data source & Short name \\
\hline Output (GDP) & $\begin{array}{l}\text { South African Reserve } \\
\text { Bank Quarterly Bulletin }\end{array}$ & $y$ \\
\hline General price indices & Statistics South Africa & $p$ \\
\hline Equity price indices & $\begin{array}{l}\text { Johannesburg Stock } \\
\text { Exchange }\end{array}$ & $q$ \\
\hline Exchange rates & $\begin{array}{l}\text { IMF's International } \\
\text { Financial Statistics } \\
\text { (IFS) rf series }\end{array}$ & $e$ \\
\hline Interest rates & $\begin{array}{l}\text { South African Reserve } \\
\text { Bank Quarterly Bulletin }\end{array}$ & $\rho$ \\
\hline Money supply & $\begin{array}{l}\text { South African Reserve } \\
\text { Bank Quarterly Bulletin }\end{array}$ & $m$ \\
\hline Household debt to income ratio & $\begin{array}{l}\text { South African Reserve } \\
\text { Bank Quarterly Bulletin }\end{array}$ & $d$ \\
\hline House price index & ABSA bank & $h$ \\
\hline Oil prices & Inet bridge & 0 \\
\hline
\end{tabular}

The final set of domestic variables and their relevant data sources are summarised in Table 3. Missing data were again approximated by interpolating the quarterly data from the annual data where available. If annual data were not available quarterly data were generated by backcasting using the average of the earliest available quarterly growth rates for that series.
Table 3

Domestic and exogenous data series and data sources.

The official policy rate in South Africa is the repurchase rate (Repo) of the South African Reserve Bank. However, this policy instrument was only introduced in 1998, rendering insufficient time-series observations for inclusion in this study. Both the three month Banker's Acceptance (BA) and 91 day Treasury bill (T-bill) rate were considered and it was proposed that the T-bill rate be used as a proxy for the domestic short-term or policy rate.

\subsection{Integration properties of the time series}

The reduced-form cointegration methodology proposed by Johansen (1988) assumes that the underlying data series within the system of equations are integrated of order one i.e. I(1). Although it is generally assumed that macroeconomic variables display $I(1)$ behaviour, the integration properties of each series are formally assessed. Recognising the fact that the Augmented Dickey-Fuller (ADF) test for unit roots may suffer power problems in small samples, the Kwiatkowski, Phillips, Schmidt, and Shin (KPSS) unit root test are also applied. The KPSS test differs from other unit root tests in that the underlying data series are assumed to be (trend-) stationary under the null as opposed to nonstationary. By applying both the ADF and KPPS unit root tests the risk of spurious inference due to low power properties displayed by the underlying unit root test is reduced (Table 4).

The unit root tests are applied to the full sample of data available i.e. from $1980 \mathrm{Q} 1$ to $2006 \mathrm{Q} 4$ for all time series. Series are tested for unit roots based on the transformation as set out above. Testing is started with the maximum lag length of the underlying AR process assuming an AR process of order 5 and the final order of the ADF test statistic is calculated based on the Akaike information criteria (AIC) in the case of the ADF test while the bandwidth of the KPPS test statistic is calculated based on the Newey-West criteria. Stationarity of variables in levels and first difference terms is tested for. For variables in level form, the ADF test statistic is evaluated assuming stationarity where there is no intercept (none), an intercept only and an intercept and trend in the underlying data-generating process while the KPPS test is evaluated with an intercept and intercept plus trend in the underlying data series. For variables in first differences, no trend stationarity specification is included, i.e. ADF tests excluding and including an intercept and KPPS tests including an intercept are applied.

In general the results from the unit root test are in line with the $a$ priori expectation and the results found in the literature. Although the KPSS test suggests that some of the domestic variables might also be $I(0)$ as apposed to $I(1)$, the ADF test indicates unambiguously that domestic variables are all $I(1)$.

The results from the global variables are similar and suggest that real output $\left(y^{*}\right)$, the price index $\left(p^{*}\right)$, real money supply $\left(m^{*}\right)$, real equity prices $\left(q^{*}\right)$ and interest rates $\left(\rho^{*}\right)$ are $I(1)$ if evaluated by either 
Table 4

Unit root test results: domestic and exogenous variables.

\begin{tabular}{|c|c|c|c|c|c|}
\hline Variables & $\begin{array}{l}\text { Unit root test } \\
\text { equation } \\
\text { specification }\end{array}$ & $\begin{array}{l}\text { ADF lag } \\
\text { length }\end{array}$ & $\begin{array}{l}\text { ADF test } \\
\text { statistic } \\
\mathrm{H}_{0} \text { : non- } \\
\text { stationary }\end{array}$ & $\begin{array}{l}\text { KPSS } \\
\text { band } \\
\text { width }\end{array}$ & $\begin{array}{l}\text { KPSS test } \\
\text { statistic } \mathrm{H}_{0} \\
\text { stationary }\end{array}$ \\
\hline \multirow[t]{3}{*}{$y$} & None & 4 & 7.40 & & \\
\hline & Intercept & 4 & 6.23 & 9 & $1.08^{*}$ \\
\hline & $\begin{array}{l}\text { Intercept } \\
\text { and trend }\end{array}$ & 4 & 2.26 & 8 & $0.31 *$ \\
\hline \multirow[t]{2}{*}{$\Delta y$} & None & 3 & $-7.44^{*}$ & & \\
\hline & Intercept & 3 & $-9.21 *$ & 10 & 1.0 \\
\hline \multirow[t]{3}{*}{$p$} & None & 0 & 1.06 & & \\
\hline & Intercept & 0 & -0.49 & 8 & $0.91 *$ \\
\hline & $\begin{array}{l}\text { Intercept } \\
\text { and trend }\end{array}$ & 0 & -1.93 & 7 & 0.14 \\
\hline \multirow[t]{2}{*}{$\Delta p$} & None & 0 & $-10.68^{*}$ & & \\
\hline & Intercept & 4 & $-6.59 *$ & 2 & 0.2 \\
\hline \multirow[t]{3}{*}{$m$} & None & 1 & 3.10 & & \\
\hline & Intercept & 1 & 2.66 & 9 & $1.05^{*}$ \\
\hline & $\begin{array}{l}\text { Intercept } \\
\text { and trend }\end{array}$ & 1 & 0.61 & 8 & $0.30^{*}$ \\
\hline \multirow[t]{2}{*}{$\Delta m$} & None & 0 & $-5.86^{*}$ & & \\
\hline & Intercept & 0 & $-6.60 * * *$ & 7 & 0.62 \\
\hline \multirow[t]{3}{*}{$q$} & None & 0 & 1.06 & & \\
\hline & Intercept & 0 & -0.49 & 8 & $0.91 *$ \\
\hline & $\begin{array}{l}\text { Intercept } \\
\text { and trend }\end{array}$ & 0 & -1.93 & 7 & $0.15^{*}$ \\
\hline \multirow[t]{2}{*}{$\Delta q$} & None & 0 & $-10.61^{* * *}$ & & \\
\hline & Intercept & 0 & $-10.68^{* * *}$ & 2 & 0.2 \\
\hline \multirow[t]{3}{*}{$\rho$} & None & 1 & -0.40 & & \\
\hline & Intercept & 4 & -3.14 & 8 & 0.38 \\
\hline & $\begin{array}{l}\text { Intercept } \\
\text { and trend }\end{array}$ & 1 & -3.70 & 8 & $0.17 *$ \\
\hline \multirow[t]{2}{*}{$\Delta \rho$} & None & 0 & $-5.87^{*}$ & & \\
\hline & Intercept & 0 & $-5.84^{*}$ & 4 & 0.14 \\
\hline \multirow[t]{3}{*}{$e$} & None & 0 & $-3.87^{*}$ & & \\
\hline & Intercept & 1 & -1.73 & 9 & $1.09 *$ \\
\hline & $\begin{array}{l}\text { Intercept } \\
\text { and trend }\end{array}$ & 0 & 1.70 & 8 & $0.25^{*}$ \\
\hline \multirow[t]{2}{*}{$\Delta e$} & None & 0 & $-9.37^{*}$ & & \\
\hline & Intercept & 0 & $-9.95^{*}$ & 2 & 0.21 \\
\hline \multirow[t]{3}{*}{$h$} & None & 1 & 0.43 & & \\
\hline & Intercept & 1 & -0.91 & 9 & 0.27 \\
\hline & $\begin{array}{l}\text { Intercept } \\
\text { and trend }\end{array}$ & 4 & -0.21 & 9 & 0.26 \\
\hline \multirow[t]{2}{*}{$\Delta h$} & None & 0 & $-3.33^{*}$ & & \\
\hline & Intercept & 0 & $-3.34^{*}$ & 8 & 0.44 \\
\hline \multirow[t]{3}{*}{$d$} & None & 1 & 1.97 & & \\
\hline & Intercept & 1 & -2.93 & 8 & 0.71 \\
\hline & $\begin{array}{l}\text { Intercept } \\
\text { and trend }\end{array}$ & 0 & -3.32 & 8 & 0.07 \\
\hline \multirow[t]{2}{*}{$\Delta d$} & None & 0 & $-10.63^{*}$ & & \\
\hline & Intercept & 0 & $-10.55^{*}$ & 6 & 0.15 \\
\hline \multirow[t]{3}{*}{$o^{*}$} & None & 0 & 0.25 & & \\
\hline & Intercept & 0 & -1.70 & 8 & 0.31 \\
\hline & $\begin{array}{l}\text { Intercept } \\
\text { and trend }\end{array}$ & 0 & -1.87 & 8 & $0.27 *$ \\
\hline \multirow[t]{2}{*}{$\Delta 0^{*}$} & None & 1 & $-9.41^{*}$ & & \\
\hline & Intercept & 1 & $-9.39 *$ & 3 & 0.19 \\
\hline
\end{tabular}

*/**/*** Indicates a rejection of the null hypothesis at a $10 / 5 / 1 \%$ level of significance.

the ADF or KPSS test statistics. We will however be guided by the literature and empirical results presented by PSW (2004) on their global variable integration tests in order to assume that all variables are weakly $I(1)$ (Table 5).

\subsection{A South African-specific VECM model}

Given the unit root results, the VECM approach is appropriate within the South African context. After careful analysis of possible theoretical relationships and multicollinearity that may exist between the variables, the set of domestic macroeconomic factors is selected to be the following: real output $(y)$; the price index $(p)$; real equity prices $(q)$; exchange rate $(e)$; interest rates $(\rho)$; real house price index
( $h$ ) and the household debt ratio (d). Due to the fact that South Africa is a small global role player, it is reasonable to assume that the South African economy can be regarded as a small open economy. Theoretically, this implies that domestic economic variables should in the long run not have a significant impact on global macroeconomic events. As such the theoretical assumption that the set of global variables is world output $\left(y^{*}\right)$, real world equity prices $\left(q^{*}\right)$ and world interest rates $\left(\rho^{*}\right)$ is imposed. While it is not the aim of this paper to obtain structural estimates for global economic factors, the variables are estimated within the GVAR model in order to provide estimates of the global factors for simulation purposes. The estimation results and forecasts from the VECM model will be evaluated for reasonability to ensure that these do not unduly bias the domestic variables' forecasts.

Cointegration and VECM techniques have become very popular and well known in the empirical econometric literature. Various asymptotic tests and procedures have been developed to test the cointegrating rank of a system as well as identify the system of equations in order to provide a unique solution. Asymptotically, these tests are very appealing and most certainly correct but in practice they are quite challenging to implement. As stated by Greenslade et al. (2000) "...for the sample sizes available in most practical situations it is argued that the interaction of dynamic identification and long-run identification can have enormous effects on the size and power of the testing procedures conventionally used" and that "...the small sample properties of now familiar cointegration tests can be very poor in many practical situations". Moreover, “...in a common realistic modeling situation of a limited data set and the theory requirements of a fairly rich model, the techniques proposed in the existing literature are almost impossible to implement successfully". Many researchers have thus been discouraged by the statistical result from their modelling efforts and abandoned it due to statistical properties that have not been satisfied completely or are not supported by economic theory. In this application the final VECM model and specification is arrived at

Table 5

Unit root test results: global variables.

\begin{tabular}{|c|c|c|c|c|c|}
\hline Variables & $\begin{array}{l}\text { Unit root test } \\
\text { equation } \\
\text { specification }\end{array}$ & $\begin{array}{l}\text { ADF lag } \\
\text { length }\end{array}$ & $\begin{array}{l}\text { ADF test } \\
\text { statistic } \\
\mathrm{H}_{0}: \text { non- } \\
\text { stationary }\end{array}$ & $\begin{array}{l}\text { KPSS } \\
\text { band } \\
\text { width }\end{array}$ & $\begin{array}{l}\text { KPSS test } \\
\text { statistic } \mathrm{H}_{0} \text { : } \\
\text { stationary }\end{array}$ \\
\hline \multirow[t]{3}{*}{$\overline{y^{*}}$} & None & 4 & 2.23 & & \\
\hline & Intercept & 4 & $-7.32^{* * *}$ & 8 & $0.35^{* * *}$ \\
\hline & $\begin{array}{l}\text { Intercept } \\
\text { and trend }\end{array}$ & 4 & $-8.25^{* * *}$ & 8 & $0.25^{* * *}$ \\
\hline \multirow[t]{2}{*}{$\Delta y^{*}$} & None & 3 & $-6.01 * * * *$ & & \\
\hline & Intercept & 3 & $-6.91 * * * *$ & 9 & 0.59 \\
\hline \multirow[t]{3}{*}{$p^{*}$} & None & 5 & 2.00 & & \\
\hline & Intercept & 5 & -1.66 & 9 & $1.17 *$ \\
\hline & $\begin{array}{l}\text { Intercept } \\
\text { and trend }\end{array}$ & 5 & -1.26 & 8 & $0.31^{*}$ \\
\hline \multirow[t]{2}{*}{$\Delta p^{*}$} & None & 4 & $-2.49 * *$ & & \\
\hline & Intercept & 4 & $-3.06^{* *}$ & 9 & 0.79 \\
\hline \multirow{3}{*}{$m^{*}$} & None & 5 & 4.04 & & \\
\hline & Intercept & 5 & -0.60 & 9 & $1.18^{*}$ \\
\hline & $\begin{array}{l}\text { Intercept } \\
\text { and trend }\end{array}$ & 4 & -2.13 & 8 & $0.15^{*}$ \\
\hline \multirow[t]{2}{*}{$\Delta m^{*}$} & None & 3 & $-2.23 * *$ & & \\
\hline & Intercept & 4 & $-4.70^{* * *}$ & 5 & 0.13 \\
\hline \multirow[t]{3}{*}{$q^{*}$} & None & 0 & 1.70 & & \\
\hline & Intercept & 0 & -0.32 & 9 & 0.0 .9 \\
\hline & $\begin{array}{l}\text { Intercept } \\
\text { and trend }\end{array}$ & 0 & $-4.20 * * *$ & 8 & 1.03 \\
\hline \multirow[t]{2}{*}{$\Delta q^{*}$} & None & 0 & $-3.67 * * *$ & & \\
\hline & Intercept & 0 & $-3.89 * * *$ & 2 & 0.15 \\
\hline \multirow[t]{3}{*}{$\rho^{*}$} & None & 4 & -1.48 & & \\
\hline & Intercept & 4 & -1.81 & 8 & $1.15^{*}$ \\
\hline & $\begin{array}{l}\text { Intercept } \\
\text { and trend }\end{array}$ & 3 & $-5.39 * * *$ & 7 & 0.06 \\
\hline \multirow[t]{2}{*}{$\Delta \rho^{*}$} & None & 5 & $-5.75^{* * *}$ & & \\
\hline & Intercept & 5 & $-5.89 * * *$ & 4 & 0.04 \\
\hline
\end{tabular}

$* / * * / * * *$ Indicates a rejection of the null hypothesis at a $10 / 5 / 1 \%$ level of significance 
and accepted considering results from economic theory, statistical correctness, in- and out-of-sample estimation results, forecast simulation outcomes, as well as keeping the specification as parsimonious as possible.

\subsection{Cointegrating rank properties of the system}

The first step in estimating the South African-specific VECM component to the GVAR model is to test the cointegrating rank of the system. As a result of the relatively short time span of available data, the order of the lag structure is assumed to be 1 and the cointegration rank tests are performed accordingly. The trace and maximum eigenvalue tests are performed, including an intercept in the cointegration equation as well as the test VAR. Test statistics and critical values are provided in Table 6.

The trace test indicates that there are 8 cointegrating relationships between the variables included in our VAR model while the maximum eigenvalue test indicates that there are only 2 cointegrating relationships. Since this difference is quite striking, it warrants the following comments.

As pointed out by Harris (1995: 88), the apparent contradiction between the trace and the maximum eigenvalue test statistic is not uncommon. He suggests the use of additional information that can support the choice of $r$. In this regard, Juselius (1995) suggests looking at the dynamics of the VAR model, and in particular, if it converges in the long run. Juselius (1995) suggests that the eigenvalues or roots of the "companion matrix" needs to be considered, since these provide additional information of the number of $(n-r)$ roots that are on the unit circle and, hence, the number of $r$ cointegrating relations. In our case, there are 20 roots of the companion matrix, since $n \times k=10 \times$ $2=20$. The moduli of the three largest roots are $0.990247,0.986628$ and 0.986628 , respectively, indicating that all roots lie inside the unit circle, with the three largest roots being close to unity. This suggests that $(n-r)=3$, and thus, two cointegrating relationships. Moreover, it is highly unlikely that there could be 8 structural theoretical relationships present within the system of 10 variables and would most certainly make it practically impossible to identify the system. As such, this study bases its inference on the maximum eigenvalue statistic which indicates 2 cointegrating equations in the system.

Table 6

Cointegration rank test statistics.

Unrestricted cointegration rank test (trace)

\begin{tabular}{|c|c|c|c|c|}
\hline $\begin{array}{l}\text { Hypothesized } \\
\text { no. of } \mathrm{CE}(\mathrm{s})\end{array}$ & Eigenvalue & $\begin{array}{l}\text { Trace } \\
\text { statistic }\end{array}$ & $\begin{array}{l}0.05 \text { critical } \\
\text { value }\end{array}$ & Prob. $^{a}$ \\
\hline None $^{b}$ & 0.668898 & 357.9437 & 239.2354 & 0.0000 \\
\hline At most $1^{\mathrm{b}}$ & 0.568988 & 269.5175 & 197.3709 & 0.0000 \\
\hline At most $2^{b}$ & 0.448352 & 202.1879 & 159.5297 & 0.0000 \\
\hline At most $3^{b}$ & 0.433694 & 154.6003 & 125.6154 & 0.0003 \\
\hline At most $4^{b}$ & 0.319116 & 109.1107 & 95.75366 & 0.0044 \\
\hline At most $5^{\mathrm{b}}$ & 0.299598 & 78.36163 & 69.81889 & 0.0089 \\
\hline At most $6^{\text {b }}$ & 0.215491 & 49.87358 & 47.85613 & 0.0319 \\
\hline At most $7^{b}$ & 0.191815 & 30.45785 & 29.79707 & 0.0419 \\
\hline At most 8 & 0.147213 & 13.42068 & 15.49471 & 0.1003 \\
\hline \multicolumn{5}{|c|}{ Trace test indicates 8 cointegrating eqn $(s)$ at the 0.05 level } \\
\hline \multicolumn{5}{|c|}{ Unrestricted cointegration rank test (maximum eigenvalue) } \\
\hline $\begin{array}{l}\text { Hypothesized } \\
\text { no. of } C E(s)\end{array}$ & Eigenvalue & $\begin{array}{l}\text { Max-eigen } \\
\text { statistic }\end{array}$ & $\begin{array}{l}0.05 \text { critical } \\
\text { value }\end{array}$ & Prob. $^{\mathrm{a}}$ \\
\hline None $^{\mathrm{b}}$ & 0.668898 & 88.42621 & 64.50472 & 0.0001 \\
\hline At most $1^{\text {b }}$ & 0.568988 & 67.32956 & 58.43354 & 0.0054 \\
\hline At most 2 & 0.448352 & 47.58759 & 52.36261 & 0.1422 \\
\hline
\end{tabular}

a MacKinnon-Haug-Michelis (1999) p-values.

b Denotes rejection of the hypothesis at the 0.05 level.

\subsection{Imposing restrictions on the VECM system}

Due to the theoretical exogeneity assumptions placed on the global variables, the remaining task is to identify two long-run cointegrating equations from a set of seven endogenous domestic variables by imposing just-identifying or over-identifying restrictions on the system. Due to the complexity of multivariate cointegration techniques and the 13 different VECM models comprising the GVAR model, it is practical for PSW (2004) to derive their country-specific VECM models based on exact identification restrictions. Although all exact-identified systems produce a just-identified system and subsequent similar forecast and impulse response estimates, these results may not always conform to economic theory. While this study does not aim to provide an unchallengeable structural relationship, but rather a theoretically consistent simulation model to be used in a South African credit portfolio model, it is necessary to ensure that the restrictions imposed on the system are in line with economic rationale. The objective is thus to identify the system as well as ensure that the coefficient estimates are consistent with expectations. The set of possible normalisation restrictions can be based on the following set of domestic variables: real output $(y)$, the price index $(p)$, real equity prices $(q)$, exchange rate $(e)$, interest rates $(\rho)$, real house price index $(h)$ and the household debt to income ratio $(d)$. It is proposed that equations for the exchange rate $(e)$ and real equity prices $(q)$ be identified.

For the real equity price $(q)$ equation the principles behind the dividend discount model used in equity stock analysis are used to derive the main components of the specification. The dividend discount model estimates the present value of a share as the value of future cash flows discounted by an appropriate interest rate. As such, real world output $(y)$ is included as a cash flow variable with interest rates as the representative discount rate. Equity prices should increase with increased future cash flows and decrease if discount rates increase. Due to the massive increase in house price asset values in recent times, many investors have substituted equities for property in order to diversify portfolios and also tap into the massive property price boom experienced in global markets. Especially in South Africa, property is the primary substitution asset for equities and therefore should be included in the specification. Increases in property values should therefore result in a substitution away from equities and into property, resulting in equity price deflation. Financial liquidity is a significant driving force behind many asset price bubbles and especially price volatility in equity markets. Many previous equity market meltdowns have resulted from liquidity draining quickly from the economic system. As a result we include the household debt to income ratio as a proxy for liquidity (due to its correlation with money supply) and expect that an increase in liquidity should lead to increases in equity prices. The domestic equity price specification is therefore:

$q=f\left(y^{*}, \rho, h, d\right)$

The second relationship that will be identified within the VECM specification is the exchange rate. Following the theoretical discussions from Abel and Bernanke (2001), the theoretical constraints, as applicable to a small open economy, are imposed. According to Abel and Bernanke (2001) one can expect that the exchange rate of a small open economy (real or nominal) could be influenced by domestic and global currency demand and supply factors. An increase in foreign income or liquidity would increase demand for domestic goods and currency resulting in a strengthening in the value of the domestic currency. Higher real rates of return on domestic assets e.g. interest rates, equity returns and property values would also increase the demand for domestic currency as more investors would be looking to invest in the domestic market. On the other hand, increases in domestic income and inflation rates would result in an increase in the demand for foreign goods and a loss in purchasing power, which would 
Table 7

VECM estimation output (cointegrating relationships).

Vector error correction estimates

Standard errors in ( ) and $t$-statistics in [ ]

Restrictions identify all cointegrating vectors

LR test for binding restrictions (rank $=2$ ):

Chi-square(10): 15.714

Probability: 0.152

\begin{tabular}{lrr}
\hline Cointegrating Eq: & CointEq1 & CointEq2 \\
\hline$\rho^{*}(-1)$ & 0.000 & 0.000 \\
$q^{*}(-1)$ & 0.000 & 0.000 \\
$y^{*}(-1)$ & 3.020 & \\
& $(1.537)$ & 0.000 \\
$e(-1)$ & {$[1.964]$} & -1.000 \\
& 0.000 & -6.465 \\
$\rho(-1)$ & -8.807 & $(1.850)$ \\
& $(1.246)$ & {$[-3.494]$} \\
$q(-1)$ & {$[-7.067]$} & -0.513 \\
& & $(0.261)$ \\
& -1.000 & {$[-1.968]$} \\
$y(-1)$ & & 5.633 \\
& & $(0.385)$ \\
$d(-1)$ & 0.000 & {$[14.641]$} \\
& & \\
$h(-1)$ & 4.073 & 0.000 \\
$p(-1)$ & $(0.400)$ & -2.460 \\
$C$ & {$[10.178]$} & $(0.212)$ \\
\hline
\end{tabular}

lead to a deterioration in the domestic currency value. The following exchange rate equation is thus proposed:

$e=f(\rho, q, y, h)$

The final theoretical specification provides a total of 12 overidentification restrictions on the system of 2 long-run cointegrating vectors, i.e. 2 normalization and 10 theoretical exclusion restrictions.

\subsection{Estimation results}

The VECM results for the theoretical specification outlined above are presented in Table 7. The estimation results of the cointegration equations are of particular interest as they would govern the long-run relationship of the model simulations in the portfolio model and should therefore provide theoretically consistent estimates of the interaction between the variables. According to the Likelihood-ratio test, the Chisquare statistic of 15.71 (probability equal to 0.15 ) indicates that the theoretical constraints placed on the system are valid and binding and identify all cointegrating vectors. While the $R$-squared values from the dynamic estimation output indicate that a significant portion of the variation in the dynamics of the variables is explained by the system, the discussion would focus on the long-run estimation results.

The first cointegrating relationship capturing domestic equity price movements illustrates the high dependence of South African financial markets on global economic conditions and prosperity. While the substitution between equity and fixed assets is still significant, domestic interest rates are clearly a very significant discounting factor. As expected the positive correlation between domestic liquidity (as proxied by the household debt to income ratio) and equity movements illustrates that equity prices can be inflated by high liquidity levels.

The second cointegrating equation represent the theoretical specification for the exchange rate and shows that the estimation results conform to economic theory. The coefficients for domestic income growth and inflation show the expected depreciation in the currency due to higher import volumes and a loss in purchasing power while increases in asset values would lead to increased demand for Rand denominated assets and a strengthening of the currency.

We have considered the possibility of a structural break in 1994 when South Africa has seen a significant change in political dispensation. The end of Apartheid allowed for increased numbers of people participating in the economy on a formal basis. Moreover, changes in fiscal and monetary policy as well as labour market reforms are all factors that have had significant impacts on the economy. Dees et al. (2007) test for structural breaks by focussing on the structural stability of their short-run coefficients, rather than that of the long-run coefficients. They use structural stability tests based on the residuals of the individual equations of the country-specific models, since these residuals only depend on the rank of the cointegrating vectors and not on the way the cointegrating relations are exactly identified. Since we have applied theoretical over-identification restrictions on the model it is important that structural breaks in the data do not render the specification invalid. In order to test for a structural change in the economy that might lead to a significant change in the cointegration equations' coefficient estimates, we have included an exogenous dummy variable (taking the value of 0 before 1994 and 1 thereafter) in the model and re-estimated the VECM. The coefficients however remain robust in the presence or absence of such variable. We therefore proceed with standard diagnostic testing on the model reported in Table 7.

\subsection{Diagnostic tests}

Due to the fact that the VECM will be used to simulate "economic states" in the credit portfolio model, it is important that the model exhibits stability in order to avoid generating unrealistic economic realisations. As such, various diagnostic tests have been performed and are presented below to assess the appropriateness of the VECM specification and also to give credence to the identification restrictions imposed in the system.

Firstly, autocorrelation tests indicate that there are no systematic patterns in the errors up to lag 4 . The errors are also normally distributed. As such, the results indicate that the model does not suffer significant miss-specification and does not possess serial correlated error terms as a result.

The next test for appropriateness is to assess the number of roots created in the AR characteristic polynomial. As outlined by PSW (2004)

\section{Inverse Roots of AR Characteristic Polynomial}

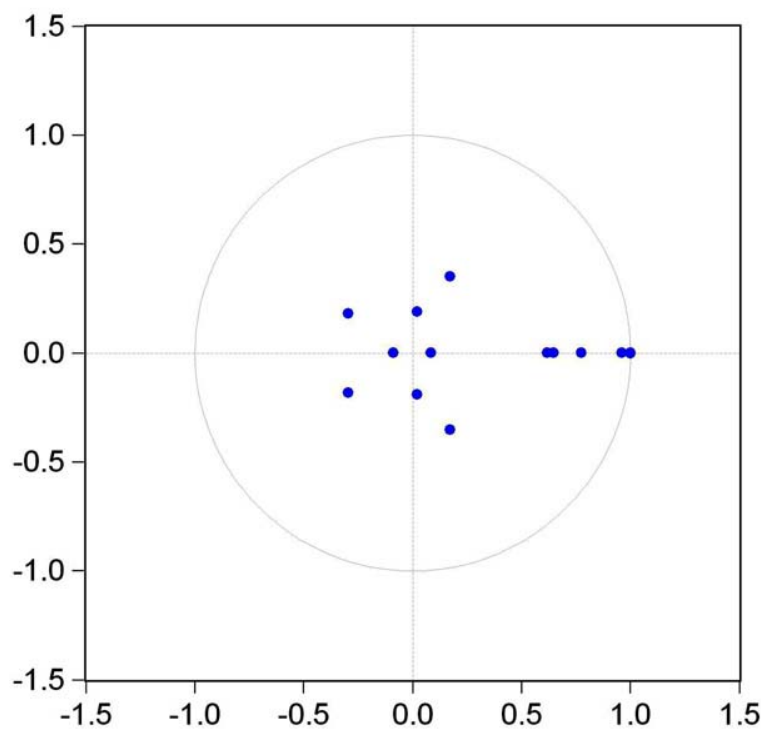

Fig. 1. Stability conditions: AR characteristic polynomial roots. 
this is a significant condition which should be met for the GVAR model to be estimated as individual country-specific models. In the VECM context, for a VECM with $r$ cointegrating relations, $k-r$ roots should be equal to unity. In the current system this implies that there should be eight $(10-2)$ unit roots. The results of the stability conditions check is summarised in Fig. 1 and shows that the VEC specification imposes the expected eight unit roots and should be significantly stable when used in simulations and forecasts within the portfolio model. These results give further support to the theoretical specification and identification restrictions imposed on the model.

\subsection{Dynamic properties of the VECM}

The estimation output shows the elasticity of the model's dependent variables to changes in the independent variables, however a more informative method of analysing the full dynamics and interdependencies of the model variables is to use general impulse response analysis (GIRF). Due to the unit root properties of the VECM model it is expected that shocks or changes in variables as imposed by general impulse response analysis should have transitory as well as permanent effects on the other variables. Although it is true that it is not “... possible to provide 'structural' or economic interpretation of
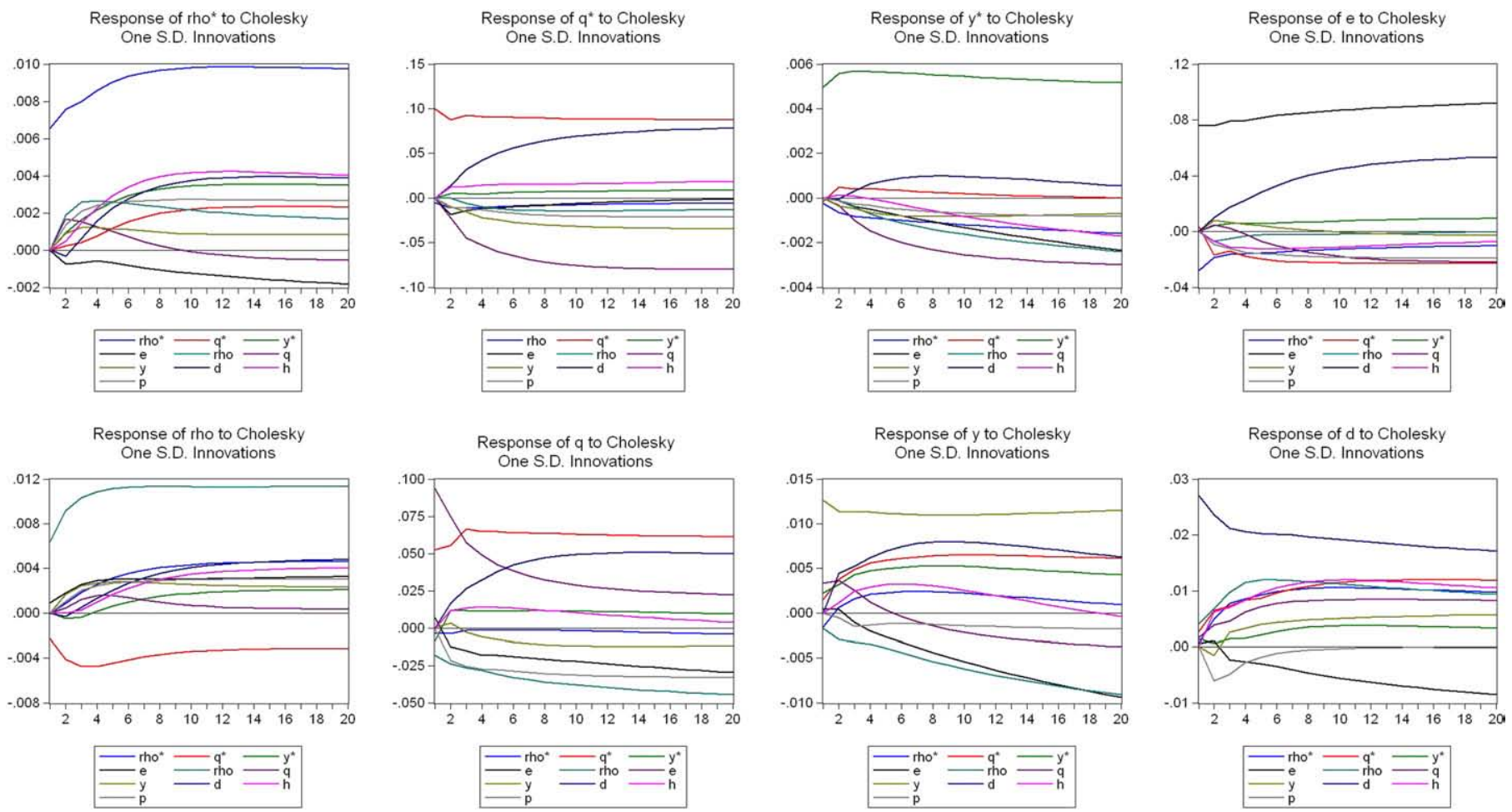

these shocks... GIRF provides a theoretically consistent account of the interdependencies of idiosyncratic shocks" (PSW, 2004).

Due to its small open economy status, South Africa is prone to be influenced significantly by international market developments. As such the impact of a generalised one standard deviation positive shock to all the variables (as apposed to only the domestic variables) in the VECM is considered and the focus falls on the time it takes for these impacts to manifest in new equilibrium levels, but more importantly, on whether the adjustment process is smooth.

The results of the GIRF analysis are summarised in Fig. 2. In general, the impulse response graphs display a smooth pattern as the endogenous variables adjust to shocks from the system. While foreign and domestic interest rates, equity prices, foreign output, the exchange rate and household debt to income levels adjust quite quickly to new levels ( 8 to 10 quarters), domestic prices, output and house prices needs up to 20 quarters (i.e. 5 years) to result in new equilibrium levels for shocks to some variables in the system, particularly shocks to exchange rate movements. This is consistent with the small open economy status of the South African economy and highlights the sensitivity of the domestic market to global market developments. The results presented here indicate that the VECM model and specification provides reasonable impact dynamics and that the model is
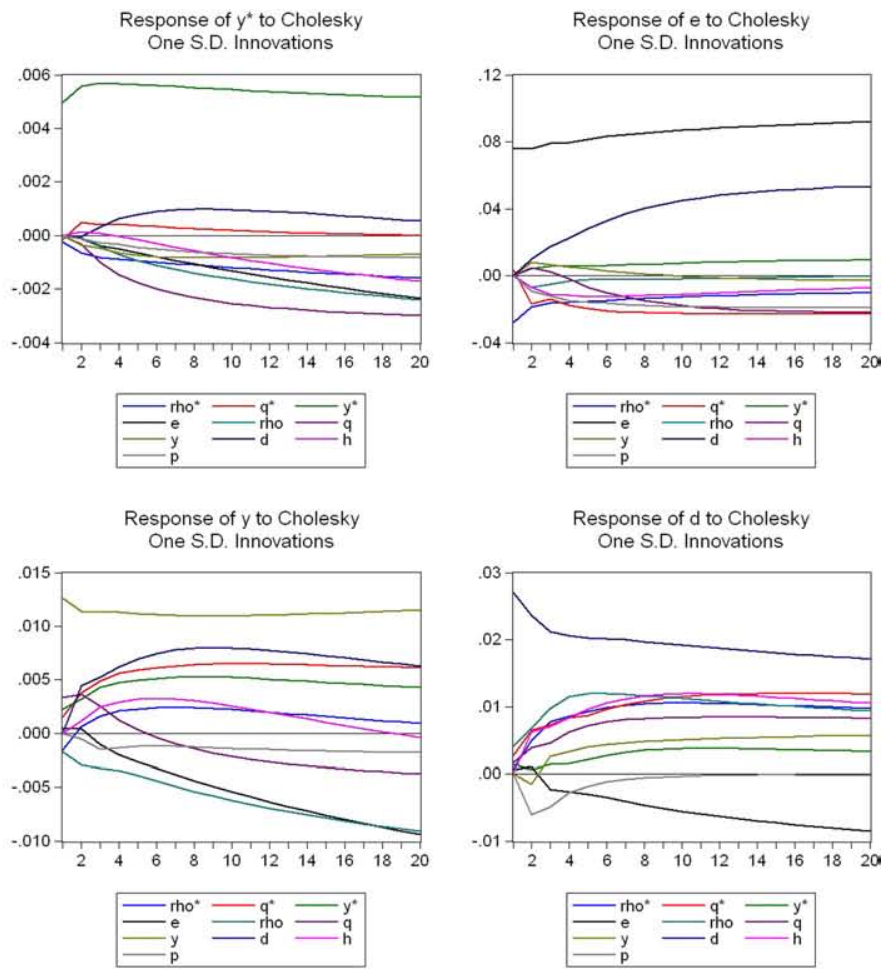

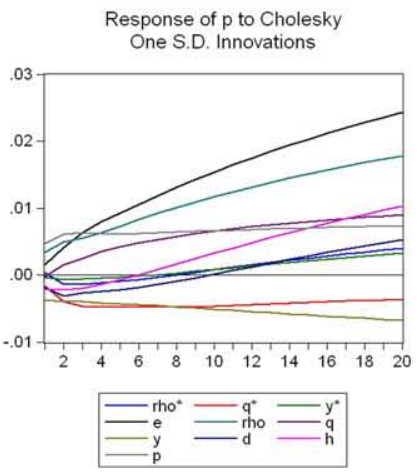

Fig. 2. GIRF analyses of global macroeconomic shocks. 

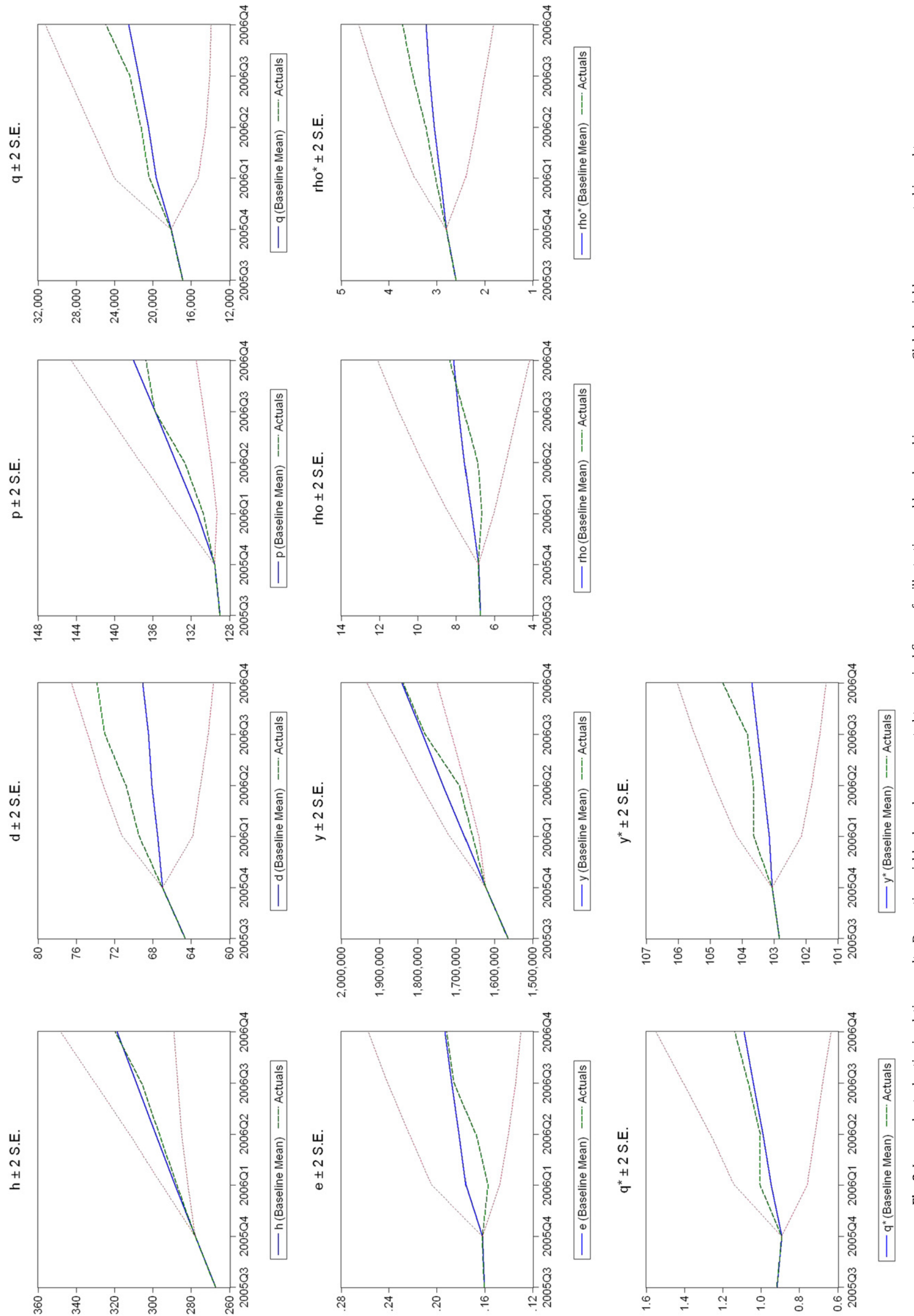

Please cite this article as: de Wet, A.H., et al., Linking global economic dynamics to a South African-specific credit risk correlation model, Econ. Model. (2009), doi:10.1016/j.econmod.2009.02.015 

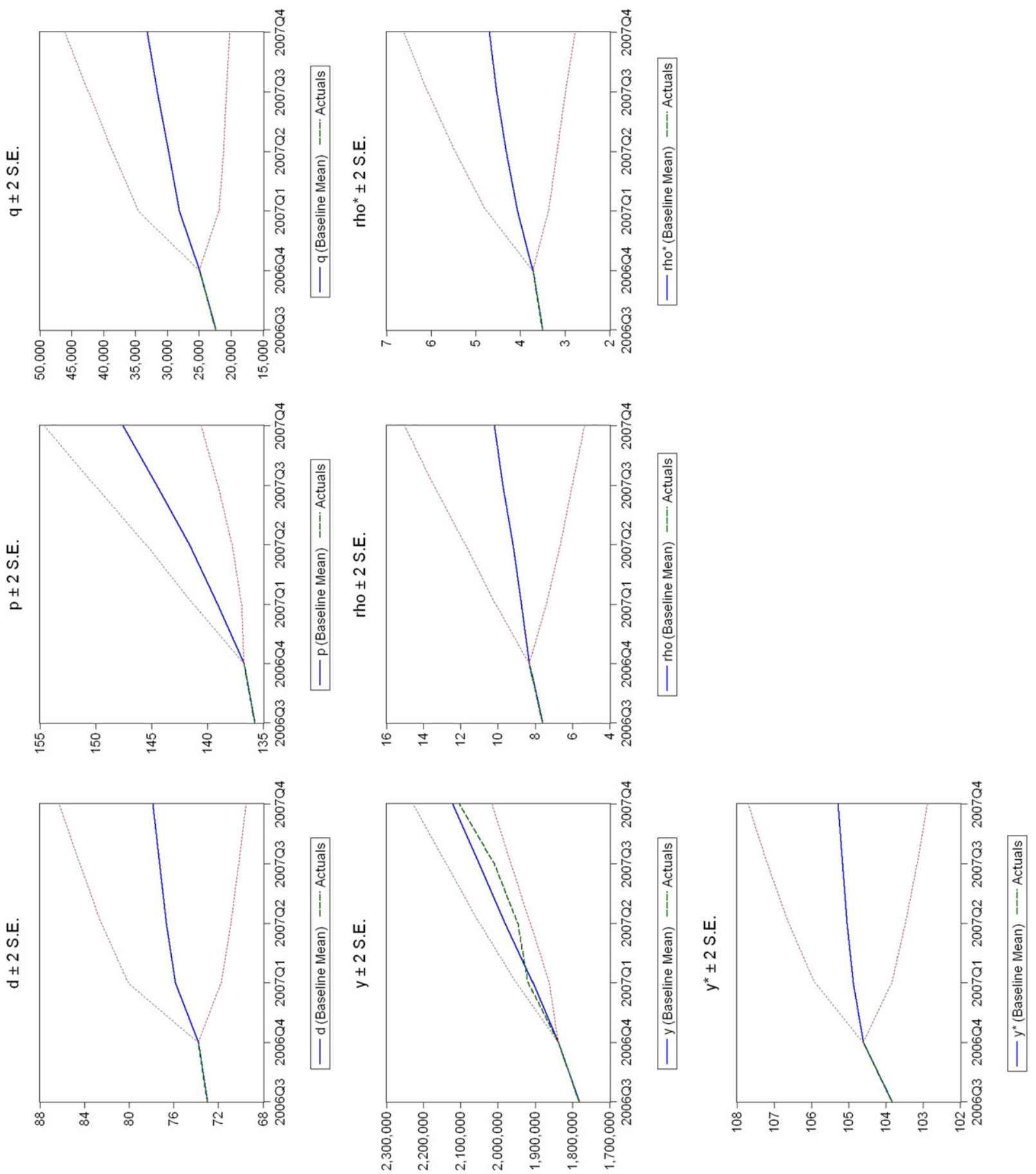

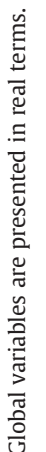

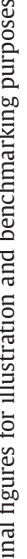
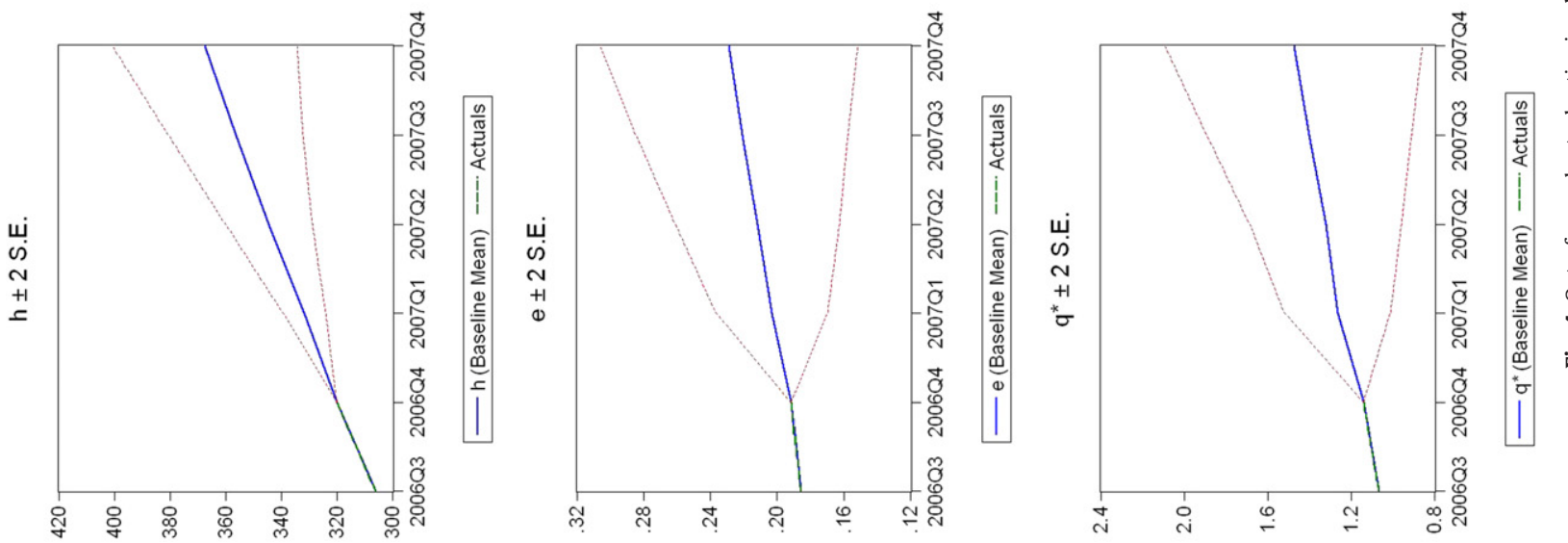
appropriate for use in forecast and scenario generation within a credit portfolio model framework.

\subsection{Stochastic forecast properties of the VECM model}

The final assessment of the appropriateness of the VECM model within the proposed credit portfolio model context is to test the model's ability to provide reasonable stochastic forecasts. Since a typical bank assesses its conditional loss distribution over a one-year period in order to allocate capital, it is essential that the VECM model provide consistent forecasts over a one-year period. The estimated VECM model is therefore simulated over a one-year period, in- and out-of-sample, i.e. from 2006Q1 to 2006Q4 and from 2007Q1 to 2007Q4 to assess forecast robustness.

The results of the in- and out-of-sample stochastic simulations are presented in Figs. 3 and 4. Analysing the in-sample simulations, except for the household debt to income ratio the VECM predicts the actual realisation of the model variables with a high degree of accuracy and does not display any significant degree of bias in variable predictions. Moreover, although the actual variable realisation may have deviated from the model predicted or expected outcomes, no such deviations fell outside the model 2-standard-error confidence intervals. Moreover, by analysing the out-of-sample results we are able to benchmark the results to some actual realisations of these variables. Specifically, the model forecasts are in line with actual GDP realisations while the end of year results for the house price index and the household debt to income ratio (actual realisations of 360 and $77.6 \%$ respectively) are also in line with its actual outcomes. As such, it is concluded that the stochastic model simulation results appropriate simulation variance to capture and include model forecast error and also provide additional variance to allow for unexpected economic events.

\section{Conclusion}

Based on the methodology proposed by PSW (2004) and PSTW (2006) this paper proposes a South African-specific credit-market correlation model which can be linked to the current GVAR model proposed by PSW (2004). The model is based on a VECM system which includes credit-market related domestic and global economic variables. Although PSW (2004) only impose statistically exact identifying restrictions on their individual country VECM model, here it is proposed that a set of theoretically consistent over-identifying restrictions be placed on the VECM system in order to identify coefficient estimates that conform to theoretical expectations.

Although it is not the aim of the model to provide forecast results for global factors, but rather to provide South African-specific elements to the GVAR model, in- and out-of-sample forecasts show that the stochastic simulations are in line with actual variable realisation and expectations. As such, it is argued that the correlation model could be employed as a stand-alone model within a South African-specific credit portfolio management tool.

\section{References}

Abel, A., Bernanke, B., 2001. Macro Economics, 4th Edition. Addison Wesley Longman, Inc.

Allen, Saunders, 2004. Incorporating systemic influences into risk measurements: a survey of the literature. J. Financ. Serv. Res. 26, 161-191.

BIS, 2006. Basel II: International Convergence of Capital Measurement and Capital Standards: a Revised Framework. Basel Committee on Banking Supervision, Basel.

Carey, M., 2002. A guide to choosing absolute bank capital requirements. Journal of Banking and Finance 26, 929-951.

Carpenter, S., Whitesell, W., Zakrajsek, E., 2001. Capital requirements, business loans and business cycles: an empirical analysis of the standardized approach in the new Basel Accord. Federal Reserve Board, Finance and Economics Discussion series, pp. 2001-2048.

Dees, S., di Mauro, F., Pesaran, H., Smith, L., 2007. Exploring the international linkages of the Euro area: a global VAR analysis. Journal of Applied Econometrics 22 (1),1-38

Elizalde, A., 2005. Do we need to worry about credit risk correlation? J. Fixed Income 15 (3), 42-59.

Greenslade, J., Hall, S., Henry, S., 2000. On the identification of cointegrated systems in small samples: practical procedures with an application to UK wages and prices. Centre for International Macro Economics. Discuss. Pap. vol. 2000, vol. 2000, p. 4.

Gordy, M., 2003. A risk-factor model foundation for ratings-based bank capital rules J. Financ. Intermed. 12, 199-232.

Harris, R.J.D., 1995. Using Cointegration Analysis in Econometric Modelling. Prentice Hall.

Jarrow, R., van Deventer, D., 2005. Estimating Default Correlations using Reduced-Form Models, Risk. Jan 2005.

Johansen, S., 1988. Statistical analysis of cointegration vectors. Journal of Economic Dynamics and Control 12, 231-254.

Johansen, S., 1989. Statistical analysis of cointegration vectors. J. Econ. Dyn. Controll 12, 231-254.

Johansen, S., 1992. Cointegration in partial systems and the efficiency of single-equation analysis. J. Econom. 52, 389-402.

Johansen, S., 1995. Likelihood-Based Inference in Cointegrated Vector Autoregressive Models. Oxford University Press, Oxford, U.K.

Juselius, K., 1995. Do purchasing power parity and uncovered interest rate parity hold in the long-run? An example of likelihood inference in a multivariate time-series model. J. Econ. 69 (1), 211-240.

Koop, G., Pesaran, M., Potter, S., 1996. Impulse-response analysis in non-linear multivariate models. J. Econ. 74, 119-147.

Pesaran, M., Shin, Y., 1998. Generalized impulse-response analysis in linear multivariate models. Econ. Lett. 58, 17-29.

Pesaran, M., Smith, R., 1998. Structural analysis of cointegrating VARs. J. Econ. Surv. 12, 471-505.

Pesaran, M., Shin, Y., Smith, R., 2000. Structural analysis of vector-error correction models with exogenous I(1) variables. J. Econom. 97, 293-343.

Pesaran, M.H., Schuermann, T., Weiner, S.M., 2004. Modeling regional interdependencies using a global error correcting macroeconometric model. J. Bus. Econ. Stat. 22 (2), 129-169.

Pesaran, M.H., Schuermann, T., Treutler, B., Weiner, S.M., 2006. Macroeconomic dynamics and credit risk: a global perspective. J. Money, Credit Bank. 38 (5),1211-1261 August 2006.

Stock, J.H., Watson, M.W., 2003. Forecasting output and inflation: the role of asset prices. J. Econ. Lit. 41 (3), 788-829.

Walters, S., De Beer, B., 1999. An indicator of South Africa's competitiveness. South African Reserve Bank Quarterly Bulletin, No. 213, September, 54-67. 